\title{
Four Perspectives of Disruption in Publication: An Inspirational White Paper
}

\author{
Dr. Julie D. Conzelmann, ORCID: https://orcid.org/0000-0003-4333-5532 \\ Dr. Jennifer Berna, ORCID: https://orcid.org/0000-0001-7006-5414 \\ Dr. Richard Bame, ORCID: https://orcid.org/0000-0001-5295-2917 \\ Dr. Crystal Davis, ORCID: https://orcid.org/0000-0002-3325-7748
}

Kellyn Miller, ORCID: https://orcid.org/0000-0002-1414-4035

Scholar Chatter Classification Genre: Business

Reference: Conzelmann, J. D., Berna, J., Bame, R., Davis, C., \& Miller, K. (2020). Four perspectives of disruption in publication: An inspirational white paper. Scholar Chatter, 1(0), 110, https://doi.org/10.47036/SC.1.0.1-10.2020

Creative Commons Attribution:

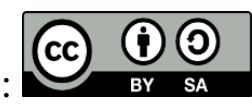

(C) The Authors. 2020. Scholar Chatter LLC is an open-access publication.

dis·rup·tion /dis' rəpSH(ə)n/

noun: disruption; plural noun: disruptions

1. A disturbance or problem that interrupts an event, activity, or process.

$$
\sim \text { Tony Robbins }
$$

The year 2020 will go down in history as a time of massive change - a total and global disruption. People were isolated in their homes for months at a time, only leaving home for necessities and emergent healthcare. Businesses were finding ways to allow employees to work remotely while keeping the organization solvent (Goldberg, 2020), and most brick and mortar universities rushed to create virtual learning platforms. Interestingly, people like me, who work remotely, should not feel disrupted; this should be the "normal" situation from dawn till dusk, time immemorial — or so one would think. I chose to add to the disruption of life — again — and I believe doing so will be as historic as it will be beneficial globally.

One of my pet peeves is the statement, "This is how we have always done things." When I stepped into my first role as an executive, staff members would stop by my office with the newly revised employee handbook I provided them and complain about job tasks and description changes. Everyone offered a statement declaring the new way as "bad," and then, that phrase, "this is how we have always done things." Those words make the same sound in my head as one 
scraping their nails on a chalkboard. I stood my ground, pointing to the handbook, looking directly into the employee's eyes, and said, "This how we will do things now."

I became the organizational disruptor - and my staff found out that I was good at it, too! Within the first four months of hire, I went from the project manager shuffling paperwork among the different departments in the organization, to overseeing organizational operations and legislative rule writing as the administrative services officer-literally the right-hand for the executive director and deputy director. Therein was the open door to organizational change processes. I saw opportunities for cross-training so that when someone called out or took vacation time, another person could double up on work to keep processes moving along. I sat down and learned each employee's job and jumped in to help if the workload became overwhelming. When my secretary was sick, I did her job so she would not come back to a pile of work on her desk. I logged the process of change daily and found that, after an entire month of working together, training, and learning what other employees were doing, employees began to see the value in the disruption and new way of doing things. The morale in the office went off the charts-I saw more smiles and camaraderie, instead of frowns and hearing incessant grumbling.

The new normal of "This is how we will do things now," however, still required a disruption now and then - but that phrase, "This is how we have always done things," began to slip into long-lost memory, and I heard it less and less among my staff. I heard, "I like job sharing, so I am not doing the same thing, all day, every day!" and "I did not realize how difficult someone else's job was until I started doing it myself! Whew!" Putting themselves in the shoes of their contemporaries provided employees a glimpse into my vision and the reason for the disruption.

The backstory here leads me to state that I was born a challenger-a disruptor, for sure! My goal is to work smarter, not harder, and always to envision where change, even if extremely difficult, would not only make processes better, timely, accurate, and lucrative for the organization but also fulfilling for the individuals involved - be it internal or external clients.

Generally, my experiences have been more from a zookeeper perspective, outside, looking inward - the fishbowl perspective, if you will. I recently had the opportunity to be both inside and outside the fishbowl. I have heard that phrase, "This is how we have always done things," and the chalkboard screeching began in my brain. I believe it is that exact experience of simultaneous situatedness that inspired this current bout of disruption - a vision of clarity and need for change that has been hidden in the skewed perspective from looking through the fishbowl.

Scholar Chatter became that vision, as proposed by speaker and motivator, Tony Robbins (2020): "Create an actionable plan for getting from where you are now to where you want to be. It puts your desire for disruption into motion"- - ergo, the goal to change to the new phase of doing things differently in the journal publication realm (Robbins, 2020). The processes of writing, revising, researching, goalsetting, fact-checking, double-blind peer-reviewing, virtual collaboration and teamwork, and accurate attribution will all culminate in the publication of error-free, concise, relevant, and informative scholarly articles. Scholar Chatter is the disruptor- 
the new journal on the web. Authors who publish with Scholar Chatter will be able to say, "THIS is how WE publish journal articles NOW!"

If you have any thoughts or questions, please email me at scholar.chatter@gmail.com

With utmost respect,

Dr. Julie "Dr. Jules" Conzelmann

CEO \& Editor-in-Chief, Scholar Chatter LLC

References:

Goldberg, J. (2020, March). The impact Of COVID-19 on U.S. brands and retailers. Forbes. https://www.forbes.com/sites/jasongoldberg/2020/03/29/the-impact-of-covid-19-on-us-brandsand-retailers/\#10c0a7eb1452

Robbins, T. (2020). What disruption really means. Tony Robbins Blog. https://www.tonyrobbins.com/career-business/what-disruption-really-means/ 
On the morning following the first Scholar Chatter LLC Advisory Board meeting, I woke and wrote in my journal about noticing clock times of 11:11 pm, 2:22 am, 4:44 am, and 5:55 am. Obviously, that was a night of disrupted sleep! During the ZOOM meeting, in a discussion of refining the Scholar Chatter journal's vision and mission statements, I had insisted and muttered about "disrupting the system" of The Way It I.S. And Always Has Been to become a published scholar.

Reflecting upon my emergence as a scholar myself, I recognize a painful experience that, at times, still warps my self-view as a scholarly writer. It occurred in a summer corporate internship finishing a second Master's degree when I had just turned 30 years young. The writing challenge was to assist the Corporate Wellness program manager, in crafting an article requested by the American Behavioral Scientist journal publishers. In describing the components of that cuttingedge corporate wellness program of national renown, I recall contributing the lion's share of the writing and designing tables and figures of the theoretical and delivery model. Interestingly, I did not realize, then, what it meant to my future writing career, to be left out of the (Smocyzk \& Dedmon, 1985) published article's list of authors. My report-to with a singular master's degree earned the first authorship, and the medical director designated himself as the second author, having edited three words. Being left off as a contributing author, I was stunned. I recalled the breadth and depth of my mentoring and writing roles, sitting daily side by side as word-smith, while the corporate manager distracted herself with "I can't do this" low esteem views of her own stilted, unpolished writing ability.

It is often through hindsight that 'meaning' in life experiences shows up. I am aware that the "left out" experience reverberated through my academic career. I consistently took a stance about not wanting or needing to 'publish or perish,' as my focus was on first and last stated legs of the tenure-worthy three-leg stool of teaching - scholarship - service. Thirty-odd years later, having quickly written and polished a single-author case study article (Berna, 2013), the reverberations were still evident.

In the past two weeks, I have mentored and edited writing of several young scholars: one in Georgia (southern USA), one in New Jersey (east coast USA), and one in Algeria. It has saddened me to hear hurdles and barriers to publishing, continuing to be The Way It Is for these ESL graduate students. That way entails feeling set aside, blocked, and buried with a lack of communication by disrespect, even haughtiness, in how they are left alone to 'figure it out' what is being requested in the editing bubbles to strengthen their academic writing.

Recently, I heard second-hand chatter how a young female colleague expressed chagrin at not crediting a male colleague's ideas on the impacts of Covid-19 pandemic as a challenging aspect of health and wellness coaching. That colleague is a person of color who has identified the common Way It Is, for White people to take credit for contributions of people of color without acknowledgment or apology. I recognize That Way also applies to disenfranchising female and ESL scholars.

In her book, Progress Not Perfection, Kate Larsen emphasizes that "Thinking patterns and unwanted behaviors are often the driving factor behind unachieved goals and a dissatisfied life" 
(2007, p 13). Larsen further identified common challenges to setting goals in order to improve upon or change health-related behavior. Several of those challenges apply to the lack of sustained success in achieving academic writing goals to complete thesis, dissertation, or article publication. Challenges to change in goal achievement behavior may include lack of focus or discipline; lack of belief that efforts are good enough; fear of rejection preventing individual risk-taking or dreaming beyond one's current reality; general lack of contentment; lack of clarity about what is really needed in goal attainment; lack of permission from oneself for dedicated writing time; and self-sabotage including a variety of avoidance behaviors and poor self-talk (Larsen, 2007). Kegan and Lahey's (2009) model of Immunity to Change advocates exploring reasons and rationale when people repeatedly resist choices to change. Coaching and mentoring services, as provided by Social Chatter leaders in the context of editorial assistance, offers writers opportunity for self-reflection, mind shift, and positive behavior change as they stretch toward their publication goals.

In These Changing Times of COVID-19 quarantine, it is time to "disrupt the system" of "Already Always Thinking and Doing Things This Way." My hope is that the first published issue of the Scholar Chatter journal is One Way to begin to disrupt the system of "The Way It Has Always Been Done" to become a published author of scholarly writing.

Sincerely,

Jennifer S. Berna, PhD (aka Dr. Jenny)

Scholar Chatter LLC Honorary Advisory Board Member

\section{References:}

Berna, J. (2013). Wellness coaching outcomes in the case of a diabetic Native American male. Global Advances in Health and Medicine, 2(4), 58-63. doi: 10.7453/gahmj.2013.027

Kegan, R., \& Lahey, L. L. (2009). Immunity to change. Boston, MA: Harvard Business Press.

Larsen, K. (2007). Progress not perfection: Your journey matters. Andover, MN: Expert Publishing.

Smocyzk, C. M., \& Dedmon, R .E. (1985, March/April). Health Management Program Kimberly-Clark Corporation. American Behavioral Scientist, 28(4). doi: 10.1177/abs.1985.027 
Locke (2003) believed that our mind is a blank slate written on by our experiences in the form of sensation and reflection. However, we are born with certain innate abilities that enable us to process any information that we receive and memory, which enables us to store the information. Locke (2003) stated, "that our mind connects our thoughts and ideas in a natural way" (p. 148). Therefore, if I burn my hand on the stove, my mind associates hot with the stove, and I know not to touch it. Locke (2003) also stated that there are instances when we connect ideas out of chance or custom when no natural connection exists. In working for the Florida Department of Transportation (FDOT), many of the people in the organization have been there a lifetime. Their favorite saying is, "that's the way we have always done it." The years have gone by, and they have no idea why "we always do it that way," helpless to change based on the unnatural connection in their minds because of custom. A custom born of an unnatural connection in their minds based on tribal knowledge or something they were told to do without any policy or procedure to give credence to the directive.

Riegel and Kegan (2020) wrote about dialectical thinking, which enables people to accept alternative truths or ways of thinking about many inconsistencies and enigmas that we face daily in life. This theory supports that the environment and experiences affect how people acquire knowledge. Cultural, social, economic, and political views all determine the development of values and knowledge (Riegel \& Kegan, 2020), aligning with the epistemological thinking of how knowledge creation within an organization takes place. Organizations today use and create knowledge in the workplace (Tsoukas, 2005), which forces us to look at organizations internally and externally when exploring knowledge claims and how it affects the organization and their external customers (Tsoukas, 2005). Organizational knowledge centers on the ability of the members in the organization to analyze and determine courses of action based on the situations presented to them. The members enact propositional statements whose application depends on their collective experience and training (Tsoukas \& Vladimirou, 2005). These generalizations, experiences, and training all sift through the spiral of knowledge, and the organizational members become more able to concentrate on new experiences in an operational sense (Tsoukas \& Vladimirou, 2005).

Scholar Chatter presents an idea of doing things differently than what is normally accepted as the way to do business. The opportunity arises to break the paradigm or create disruption and move forward in a new direction in the world of journals. An opportunity to create change that may only come to fruition through leadership and furthering knowledge through the spiral of knowledge will break this paradigm, thus creating new knowledge that evolves with the organization.

Sincerely,

Richard "Dr. Rick" Bame

Scholar Chatter LLC Honorary Advisory Board Member

References:

Locke, J. (2003). An essay concerning human understanding. In P. Moser \& A. vander Nat (Eds.), Human knowledge: Classical and contemporary approaches (pp. 128-149). NewYork, NY: Oxford University Press. 
Riegel, K. F., \& Kegan, P. (2020). Cognitive development in adulthood. In S. B. Merriam \& L. M. Baumgartner Learning in Adulthood: A Comprehensive Guide (pp. 346-374). John Wiley \& Sons.

Tsoukas, H. (2005). Introduction: Professor Bleent, the floon beetle, and organizational epistemology. In H. Tsoukas, (Ed.) Complex knowledge: Studies in organizational epistemology (pp. 1-9). New York, NY: Oxford University Press.

Tsoukas, H. \& Vladimirou, E. (2005). What is organizational knowledge? In H. Tsoukas (Ed.), Complex knowledge: Studies in organizational epistemology (pp. 117-140). New York, NY: Oxford University Press. 
Welcome to Scholar Chatter, LLC! This publication company births out of the call for a disruptive publishing company that provides a one-stop-shop for researchers to publish their work continuing in the marketplace to use rigor and high standards for the published word. Scholar Chatter, LLC intends to publish articles, essays, research, and theory across genres in the hopes of allowing researchers to have their works published.

In a disruptive manner, Scholar Chatter, LLC, allows the Authors to retain copyrights to intellectual property and will have editors on board with the company so that everything is done in-house. Our goal is for you to become a published author, and we understand how complicated the process can be and how few authors get published. We are here to disrupt that and assist each researcher in becoming published. We offer a variety of packages for researchers as we understand one size does not fit all.

Early-adopters, according to Investopedia.com, "refers to an individual or business who uses a new product, innovation, or technology before others" (Investopedia.com). Scholar Chatter, LLC, opens up the marketplace to those researchers who, in the past, have had a difficult time in getting their research due to low acceptance rates of already established journals. We will disrupt the journal world by offering a full range of services that help researchers from initiation through article acceptance. Indeed, it is our mission to fill the gap in research, disrupt the norm, and publish articles while upholding the scholarly standards of rigor and truth.

Sincerely,

Dr. Crystal Davis,

Scholar Chatter LLC Honorary Advisory Board Member

References

Early Adopter. (2019). Investopedia. https://www.investopedia.com/terms/e/early-adopter.asp 
While at first the term "disrupt" may evoke negative connotations, such as for a child who walks in on her dad's Zoom video call, or experiencing a fender bender in the middle of an already busy day, I choose to see it through a positive, even exciting lens. Merriam-Webster (2020) defined the word disrupt as, "To interrupt the normal course or unity of" an industry, establishment, or way of doing something. Ironically, disruption, itself, is nothing new. However, each time another forward-thinking individual creates a new spin on the status quo, the impact of the disruption causes society to sit up and pay attention.

Higgins and Bourne (2018) wrote, "As human beings we tend to be averse to change and resistant to anything that threatens the status quo," meaning people generally are habituated to a certain method of practice, because it is known, and comfortable. The challenging or disrupting of established customs usually results in mixed reactions, but in some cases, the disruption leads to revolutionary change. Consider when the first personal computers hit the market, or when Steve Jobs first revealed the iPhone. Uber is an example of a disruption to the taxi industry. Even online college classes were disruptive at first, and now they are commonplace. Community colleges employ online classes frequently, as explained by Christensen et al. (2006), "This has made community colleges an acceptable and even desirable choice for students' first two years. In fact, these schools now enroll some $44 \%$ of all undergraduates in the United States. They provide a good-enough alternative for prospective undergraduates.". In capturing such a large portion of the undergraduate population, one could argue that community colleges are using a once-disruptive device (online classes), to become disrupters themselves in the world of academia. With the introduction of the new online journal publication, Scholar Chatter, we once again see a disruption in an established arena.

To effectively disrupt, an organization must challenge the status quo, change the paradigm of an established practice, and excite people about the topic at hand. While journal publications exist all over the world, in various formats, what Scholar Chatter brings to the table, is a new way of looking at journal publications, particularly for researchers who want a platform for their written word. As Christensen et al. (2006) wrote, “...the catalytic innovations that will bring new benefits to the most people are likely to come from outside the ranks of the established players"; Scholar Chatter is just such a catalytic innovation.

Bringing a fresh approach to scholarly publications, this new journal will excite those who feel disenfranchised by what is currently in existence. Author Jean-Marie Dru (2015) explained this type of disruption as occurring because "People innovate either where they think change is needed or because they believe they have something new to offer." At Scholar Chatter, authors will receive strong support throughout article development and publication, in an unparalleled collaborative process. Christensen et al. (2006) concluded, "Disruptive innovations have had a major impact on industry structures, from travel to computer retailing to communications, and have often given rise to social change in the process." With its novel approach to the practice of journal publication, Scholar Chatter is the disruption researchers have been waiting for!

Sincerely,

Kellyn Miller,

Scholar Chatter LLC Honorary Advisory Board Member 
References:

Christensen, C. M., Baumann, H., Ruggles, R., \& Sadtler, T. (2006). Disruptive innovation for social change. Harvard Business Review, 1-8. http://www.cnid.cl/wpcontent/uploads/2015/10/Disruptive-Innovation-for-Social-Change_2006.pdf

Dru, J. (2015). The ways to new: 15 paths to disruptive innovation. Wiley.

Higgins, D., \& Bourne, P. A. (2018). Implementing change in an organization: A general overview. Scholarly Journal of Psychology and Behavioral Sciences, 1(1). doi:10.32474

Merriam-Webster. (n.d.). Disrupt. In Merriam-Webster.com dictionary. https://www.merriamwebster.com/dictionary/disrupt 